ABDIMAS: Jurnal Pengabdian Masyarakat Universitas Merdeka Malang
Vol.6(2) May 2021, 271-278
L-ISSN: 2721-138X e-ISSN: 2548-7159
Uttp://jurnal.unmer.ac.id/index.php/jpkm

\title{
Upaya Meningkatkan Sistem Kekebalan Tubuh Anak Usia Sekolah di Masa Pandemi COVID-19
}

\author{
Hotimah Masdan Salim¹, Tri Wahyuni Bintarti², Fifi Khoirul Fitriyah³, Ilham Putra Alam4, Davida \\ Sajid Muhammada ${ }^{4}$, Nadia Nisaussholihah ${ }^{4}$
}

'Departemen Biokimia Kedokteran, '2Departemen Biologi Kedokteran, Fakultas Kedokteran, ${ }^{3} F a k u l t a s$ Keguruan dan Ilmu Pendidikan, ${ }^{4}$ Fakultas Kedokteran, Universitas Nahdlatul Ulama Surabaya

J. Raya Jemursari No.57, Surabaya, 60237, Indonesia

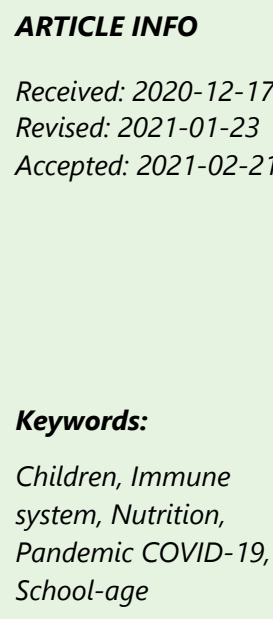

\section{ABSTRACT}

COVID-19 is a SARS virus infection that has spread throughout the world including in Indonesia. The existence of this pandemic has a significant impact on all countries, such as health, economy, education, and all supporting sectors of a country. In Indonesia itself adapting the New Normal to deal with this global pandemic. New Normal is associated with new habit changes that also impact the health level of children. So, the purpose of community service (PKM) is to provide education as an effort to increase the child's immune system in the face of the COVID-19 pandemic. This PKM is implemented at the Baca Rumah Kita Foundation in the Mejoyo Tenggilis sub-district. This PKM is carried out by presenting counseling to school-age children with interactive methods and games as well as health checks as screening and providing supplements to improve the child's immune system. Based on the PKM results, it was found that the children were enthusiastic about this activity. From the results of health screening, participants aged 5-10 years were $84.21 \%$. With a nutritional status of $47.37 \%$ less, $15.79 \%$ less nutrition, $26.32 \%$ good nutrition, and $10.53 \%$ over nutrition. Based on the results of this screening, it can be used as a measure that the growth and development of children in this region needs special attention, especially during the current pandemic.

(C) 2021 Published by University of Merdeka Malang. This is an open access article distributed under the CC BY-SA 4.0 license (https://creativecommons.org/licenses/by-sa/4.0/)

How to cite: Salim, H. M., Bintarti, T. W., Fitriyah, F. K., Alam, I. P., Muhammada, D. S., \& Nisaussholihah, N. (2021). Upaya Meningkatkan Sistem Kekebalan Tubuh Anak Usia Sekolah di Masa Pandemi COVID-19. Abdimas: Jurnal Pengabdian Masyarakat Universitas Merdeka Malang, 6(2), 271-278. https://doi.org/10.26905/abdimas.v6i2.5001

\section{PENDAHULUAN}

Pada Maret 2020 COVID-19 terdeteksi pertama kali di Indonesia, dengan angka kasus COVID-19 terus meningkat seiring berjalannya waktu. Indonesia dan negara lainnya di dunia mengandalkan strategi dengan melakukan pembatasan sosial untuk memperlambat penyebaran COVID-19. Pandemi COVID-19 yang sedang dialami seluruh negara sangat mempengaruhi kondisi kesehatan, ekonomi, pendidikan, 
ABDIMAS: Jurnal Pengabdian Masyarakat Universitas Merdeka Malang Volume 6, No. 2, May 2021: 271-278

dan lainnya. Saat ini, pemberantasan COVID-19 lebih berfokus pada masyarakat yang memiliki faktor komorbid dan kurang memperhatikan populasi pada anak. PBB telah menghimbau bahwa pandemi COVID-19 ini berdampak pada anak-anak di seluruh dunia. Penelitian sebelumnya telah menjelaskan bahwa pandemi COVID-19 telah menyebabkan gangguan kondisi nutrisi di seluruh dunia, terutama di negara-negara dengan low-income and middle-income countries (LMICs) (Laborde et al., 2020). Kondisi ini berdampak pada anak-anak, sehingga dilakukan beberapa strategi dalam menanggapi COVID-19 yaitu menjaga jarak, penutupan sekolah, pembatasan perdagangan, penutupan sekolah, dan penutupan akses suatu negara yang berefek pada pemenuhan sistem pangan dan mengganggu produksi, serta penjualan pangan sehingga membuat jutaan keluarga kekurangan gizi (Roberton et al., 2020). UNICEF telah melaporkan pada awal terjadinya COVID-19 terjadi penuruanan nutrisi sebesar 30\% dan hampir $70 \%$ terjadi pada negara dengan LMICs, dengan taksiran sekitar 2,4 miliar upaya mencegah dan mengobati malnutrisi pada anak (Roberton et al., 2020).

Pandemi COVID-19 memiliki dampak yang sangat signifikan pada kehidupan keluarga di Indonesia. Sekitar 3 juta orang kehilangan pekerjaan atau mata pencaharian mereka, anak-anak tidak lagi dapat mengakses program pemberian makanan bergizi untuk anak sekolah dan beberapa keluarga berjuang untuk membeli makanan yang biasa mereka konsumsi. Orang-orang harus menghabiskan lebih banyak waktu di rumah dan mungkin akan terjadi perubahan konsumsi makan menjadi kurang beragam, serta meningkatnya konsumsi makanan olahan dan berkurangnya konsumsi makanan bergizi, termasuk buah-buahan dan sayuran segar. Keadaan saat ini dapat memperburuk situasi yang sebelumnya telah dihadapi banyak keluarga dalam mendapatkan makanan berkualitas yang terjangkau. Sistem dan rantai pasokan pangan saat ini terganggu karena pembatasan sosial (WHO, 2020).

Dengan munculnya pandemi COVID-19 ini merupakan tantangan yang kompleks dalam menangani masalah gizi di Indonesia. Kondisi ini berdampak signifikan terhadap keamanan pangan rumah tangga yang akan mempengaruhi kondisi gizi anak. Survei yang dilakukan oleh Hanna \& Olken (2020) mendapatkan bahwa 36\% reponden menyatakan mengurangi porsi makan karena masalah keuangan (Wiresti, 2020). Hal ini disebabkan karena hilangnya pendapatan rumah tangga sehingga meningkatkan resiko anak kekurangan gizi. Kematian merupakan resiko tinggi pada anak dengan kondisi kekurangan gizi sebesar 12 kali lipat dibandingkan kondisi normal (Laborde et al., 2020).

Tenggilis Mejoyo merupakan salah satu wilayah di Kota Surabaya yang penduduknya masih memiliki tingkat pendidikan yang kurang. Berdasarkan laporan dari Yayasan Rumah Kita yang merupakan salah satu rumah singgah tempat anak-anak kurang mampu belajar, menjelaskan bahwa masih banyak anak-anak disekitar wilayah Mejoyo yang mempunyai postur tubuh kurus. Dengan pandemi saat ini, dikhawatirkan bahwa anak-anak tersebut mengalami kondisi gizi yang semakin menurun. Sehingga perlu diberikan perhatian khusus terkait kesehatan terutama pada anak-anak dalam menghadapi masa pandemi COVID-19. Adapun tujuan dari pengabdian kepada masyarakat ini adalah upaya peningkatan sistem imun pada anak usia sekolah melalui screening status gizi dan pemberian suplemen vitamin dalam mencegah penyebaran COVID-19 


\section{METODE}

Metode pelaksanaan kegiatan pemberdayaan kepada masyarakat adalah dengan menggunakan pendekatan penyuluhan untuk menyampaikan informasi agar dapat diaplikasikan sebagai salah satu upaya pencegahan dan penerapan hidup bersih dan sehat. Serta pendekatan monitoring dengan melakukan pemeriksaan dan peningkatan status gizi dengan pemberian susu dan multivitamin.

Kegiatan pengabdian masyarakat ini bermitra dengan Rumah Baca Yayasan Kita yang berkontribusi menyediakan tempat untuk membantu dalam pelaksanaan kegiatan pengabdian kepada masyarakat. Adapun sasaran kegiatan pengabdian kepada masyarakat ini adalah anak-anak usia sekolah yang belajar di Rumah Baca Yayasan Kita yang terletak di Jalan Tenggilis Mejoyo, Surabaya yang terdiri dari laki-laki dan perempuan dengan rentang usia anak usia sekolah. Hal ini bertujuan sebagai upaya peningkatan sistem imun dan evaluasi status gizi anak pada masa pandemi COVID-19.

Persiapan kegiatan ini dilakukan dengan penyuluhan interaktif dengan menggunakan material poster dan permainan. Hal ini dilakukan karena sasaran pada kegiatan ini adalah anak-anak, sehingga menggunakan metode yang interaktif dan menarik bagi anak-anak. Setelah diberikan pemahaman tentang kebutuhan gizi anak-anak, dilanjutkan dengan pemeriksaan kesehatan untuk monitoring dan evaluasi status gizi anak. Hal ini dilakukan dengan mengukur tinggi badan dan juga berat bedan

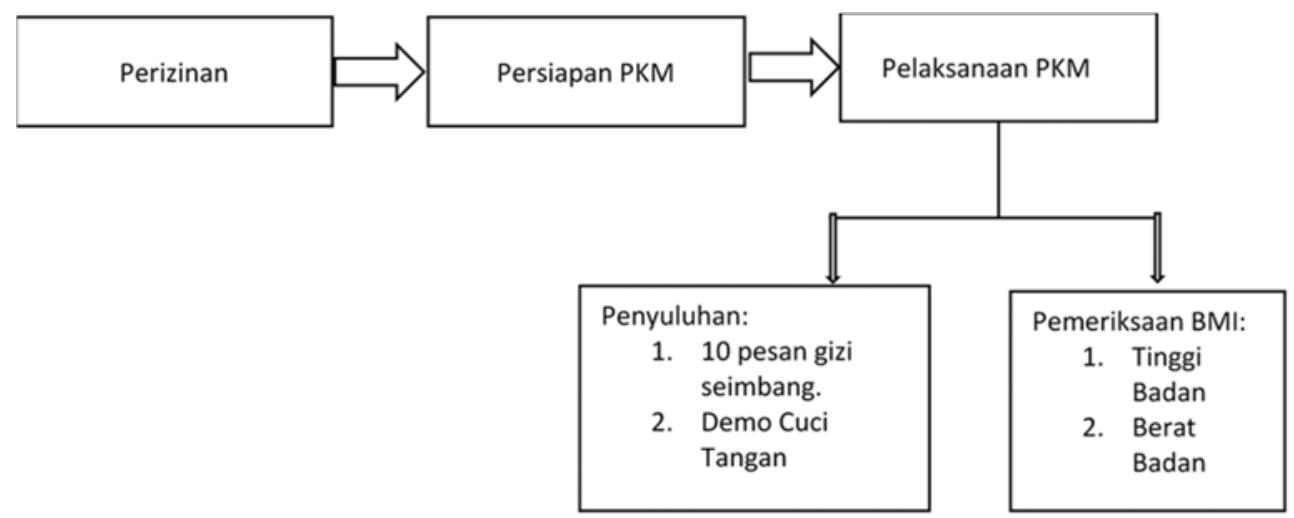

Gambar 1. Alur kegiatan pengabdian kepada masyarakat

Tabel 1. Metode kegiatan pengabdian kepada masyarakat

\begin{tabular}{lll}
\hline \multicolumn{1}{c}{ Kegiatan } & \multicolumn{1}{c}{ Metode } & \multicolumn{1}{c}{ Tujuan } \\
\hline $\begin{array}{l}\text { Penyuluhan dengan tema Upaya men- } \\
\text { ingkatkan Status Gizi dengan Penera- } \\
\text { pan 10 langkah". }\end{array}$ & $\begin{array}{l}\text { Penyuluhan interaktif dengan } \\
\text { permainan dengan mengguna- } \\
\text { kan media POSTER }\end{array}$ & $\begin{array}{l}\text { Untuk meningkatkan pemahaman terhadap } \\
\text { gizi seimbang dan upaya pencegahan penu- } \\
\text { laran COVID-19. }\end{array}$ \\
Skrining Body Mass Index (BMI) & $\begin{array}{l}\text { Pemeriksaan Tinggi Badan dan } \\
\text { Berat Badan }\end{array}$ & Untuk melihat status gizi anak \\
Meningkatkan sistem imun & Pembagian suplemen vitamin & $\begin{array}{l}\text { Meningkatkan sistem imun dengan suplemen } \\
\text { vitamin. }\end{array}$ \\
\hline
\end{tabular}


ABDIMAS: Jurnal Pengabdian Masyarakat Universitas Merdeka Malang

Volume 6, No. 2, May 2021: 271-278

\section{HASIL DAN PEMBAHASAN}

\section{Hasil}

Kegiatan pengabdian kepada masyarakat ini dilakukan atas dasar bahwa saat masa pandemi saat ini diperlukan perhatian lebih untuk memonitor kesehatan dan status gizi anak-anak usia sekolah. Hal ini bertujuan sebagai salah satu upaya dalam meningkatkan sistem kekebalan tubuh anak agar terhindar dari penyebaran infeksi maupun penyakit yang lain. Pelaksaan ini dilakukan di lingkungan Kecamatan Tenggilis Mejoyo karena wilayah ini cukup padat dengan risiko penyebaran COVID-19 cukup tinggi sehingga diperlukan perhatian khusus terutama anak-anak yang bertempat tinggal di daerah ini.

Pengabdian masyarakat dengan tema "Peningkatan Sistem Imun pada anak usia sekolan pada masa Pandemi" ini dilaksanakan pada tanggal 16 Oktober 2020 di Rumah Taman Baca Yayasan Rumah Kita. Kegiatan pertama adalah penyuluhan tentang "10 Pesan Gizi Seimbang". Absensi diberikan kepada peserta untuk mengetahui jumlah peserta yang hadir. Adapaun distribusi karakteristik peserta pengabdian yang hadir di tunjukkan pada Tabel 2 dan Gambar 2;

Tabel 2. Distribusi usia peserta pengabdian kepada masyarakat

\begin{tabular}{|c|c|c|}
\hline Usia & Jumlah & Persentase \\
\hline$<5$ & 1 & 5,26 \\
\hline 5-10 tahun & 16 & 84,21 \\
\hline$>10$ tahun & 2 & 10,53 \\
\hline Total & 19 & 100,00 \\
\hline
\end{tabular}

Pada Tabel 2 terlihat bahwa sebagian besar dari keseluruhan peserta berusia 5-10 tahun (84,21\%), dan hanya $10 \%$ peserta berusia lebih dari 10 tahun. Sedangkan distribusi jenis kelamin di tunjukkan pada Gambar 2.
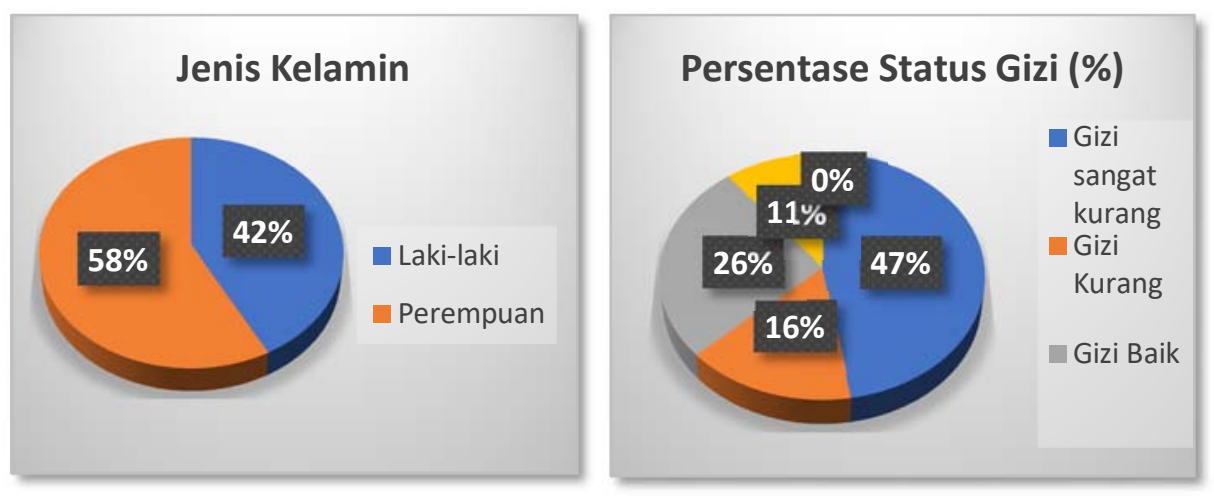

Gambar 2. Distribusi jenis kelamin

Gambar 3. Persentase status gizi 
Berdasarkan Gambar 2 menunjukkan bahwa distribusi jenis kelamin peserta pengabdian kepada masyarakat sebagian besar adalah perempuan dengan persentase $58 \%$ dan laki-laki sebesar $42 \%$
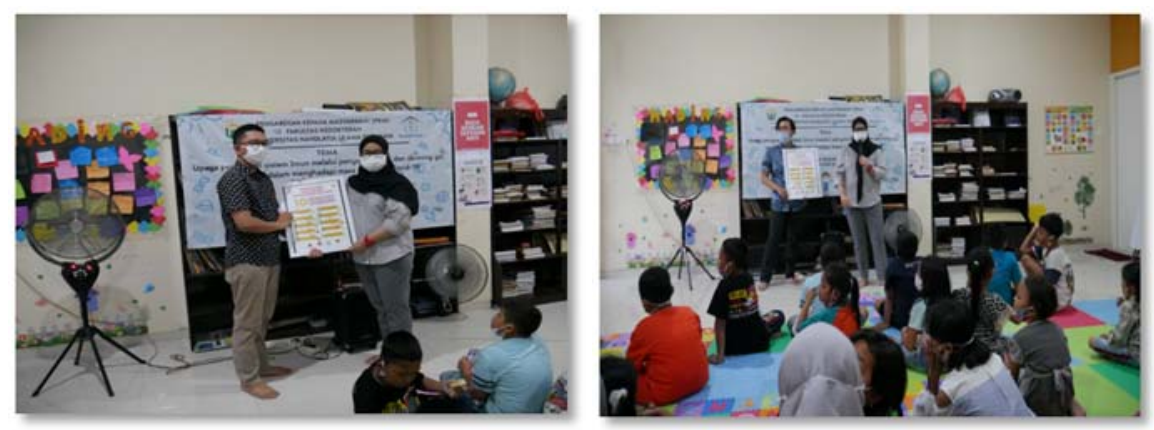

Gambar 4. Penyerahan poster

Gambar 5. Pemberian penyuluhan 10 gizi seimbang

Setelah dilakukan penyuluhan tentang 10 pesan gizi seimbang, dilanjutkan dengan pemeriksaan status gizi dan pemberian multivitamin serta susu. Adapun distribusi status gizi pada peserta pengabdian ini di tunjukkan pada Tabel 3.

Tabel 3. Karakteristik status gizi peserta pengabdian kepada masyarakat

\begin{tabular}{rlc}
\hline \multicolumn{1}{c}{ IMT } & \multicolumn{1}{c}{ Status Gizi } & Persentase Status Gizi (\%) \\
\hline$<17.0$ & Gizi sangat kurang & 47,37 \\
$17.0-18.5$ & Gizi Kurang & 15,79 \\
$18.5-25.0$ & Gizi Baik & 26,32 \\
$25.0-27.0$ & Gizi Lebih & 10,53 \\
$>27$ & Obesitas & 0,00 \\
\hline Total & & 100,000 \\
\hline
\end{tabular}

Berdasarkan data pada Tabel 3 menunjukkan bahwa status gizi peserta pengabdian masyarakat ini yang di tunjukkan dengan perhitungan Body Mass Index (BMI) berada pada status gizi sangat kurang dan ditunjukkan pada Gambar 3 dengan persentase 47,37\%, hanya 26,32 \% status gizi anak pada kondisi normal, 10,53\% dengan status gizi lebih.

\section{Pembahasan}

Berdasarkan hasil kegiatan pengabdian kepada masyarakat ini terlihat bahwa pelaksanaan kegiatan ini merupakan sarana untuk belajar dan memberikan pengetahuan tentang keseimbangan gizi pada anak-anak usia sekolah. Dengan metode interaktif dan permainan kegiatan ini akan dapat menumbuhkan kesadaran pada anak-anak tentang hidup sehat. Berdasarakan karakteristik distribusi peserta pada pengabdian kepada masyarakat ini menunjukkan bahwa peserta merupakan anak-anak usia sekolah yang terbanyak pada usia 5 tahun sampai 10 tahun, yaitu rentang usia sekolah dasar. 
ABDIMAS: Jurnal Pengabdian Masyarakat Universitas Merdeka Malang Volume 6, No. 2, May 2021: 271-278

Hal ini menunjukkan bahwa usia sekolah cukup banyak yang tinggal di Daerah Tenggilis. Selain itu, berdasarkan hasil pemeriksaan status gizi anak dengan pendekatan perhitungan body mass index (BMI) menunjukkan bahwa hampir setengah dari peserta mempunyai status gizi sangat kurang dan hanya $26 \%$ yang mempunyai status gizi normal. Berdasarkan temuan ini, menunjukkan bahwa kondisi anak-anak di Tenggilis Mejoyo membutuhkan perhatian lebih untuk meingkatkan status gizi.

Pandemi COVID-19 telah menyebabkan banyak dampak pada individu, komunitas, dan masyarakat di seluruh dunia, terutama di negara terbatas sumber daya (Forichon, 2020), dimana sistem kesehatan dan ekonomi secara keseluruhan menghadapi banyak kendala secara signifikan. Serta untuk anak-anak dan remaja merupakan tantangan yang cukup besar yang ditimbulkan akibat pandemi ini yang mengancam dan berdampak secara langsung, baik jangka menengah dan jangka panjang. Status gizi pada anak sangat mempengaruhi proses pertumbuhan dan pekembangan anak. Penilaian pertumbuhan anak harus dilakukan secara berkala, karena banyak masalah fisik maupun psikologi yang dapat mempengaruhi pertumbuhan anak. Dimana dapat terlihat bahwa pertumbuhan yang terganggu dapat dilihat dari masalah gizi dan kesehatan sebagai tanda awal. Standar status gizi dan kesehatan anak telah diatur dalam Peraturan Menteri Kesehatan Republik Indonesia Nomor 2 tahun 2020. Masalah kekurangan gizi ini sangat berhubungan dengan gangguan pertumbuhan stunting (pendek), dimana telah tercatat bahwa angkat stunting akibat kekurangan gizi di Indonesia sebesar 30,79\% pada tahun 2018 (Balitbangkes, 2018). Kondisi status gizi anak ini menjadi perhatian khusus pada masa pandemi COVID-19 saat ini, dimana diprediksi akan meningkat sekitar $15 \%$ atau 7 juta jiwa diseluruh dunia pada tahun pertama pandemi COVID-19. Dijelaskan juga bahwa setiap penurunan satu persen dari produk domestic bruto global (Forichon, 2020), maka akan terjadi peningkatan jumlah anak stunting sebanyak 0,7 juta di seluruh dunia. Hal ini sangat berkaitan, karena di masa pandemi saat ini terjadi gangguan terhadap pasokan makanan dan layanan kesehatan (WHO, 2020).

COVID-19 ini tidak hanya berdampak pada kondisi nutrisi tetapi juga dapat berdampak pada kondisi mental, hal ini telah dibuktikan pada penelitian sebelumnya di India bahwa kecemasan dan stress meningkat pada anak yang kelurganya merdampak oleh COVID-19, sehingga mengganggu kesehatan mental (Kumar et al., 2020). Penelitian sebelumnya telah menunjukkan bahwa terjadi peningkatan stunting pada anak-anak di masa pandemi COVID-19 (Jawaldeh et al., 2020). Peningkatan malnutrisi pada anak-anak seperti fenomena gunung es, dimana terus meningkat tanpa terlihat baik itu stunting, defisiensi mikronutrien dan obesitas (UNICEF, 2014). Kegagalan dalam pencegahan secara global pada kondisi pandemi saat ini akan memiliki konsekuensi jangka panjang dan akan merusak masa depan anak-anak, kehidupan manusia dan ekonomi nasional. Sehingga pencegahan dan pengobatan kepada anak-anak dengan gangguan nutrisi sangat penting. Oleh karena itu, sebagai salah satu upaya screening status gizi pada anak d imasa pandemi saat ini perlu dilakukan secara masif. Hasil yang di dapatkan dari pengabdian kepada masyarakat ini merupakan data dasar dan awal sebagai pencatatan monitoring status gizi anak usia sekolah di Kecamatan Tenggilis Mejoyo sehingga perlu dilakukan monitoring dengan memeriksan status gizi setiap bulan. 


\section{SIMPULAN DAN SARAN}

Berdasarkan hasil kegiatan pengabdian kepada masyarakat yang telah dilakukan dan bekerjasama dengan Taman Baca Yayasan Kita menemukan bahwa masih banyak anak-anak dengan status kekurangan gizi yang mana hal ini dapat mempengaruhi sistem imun dalam upaya pencegahan pada masa pandemi COVID-19.

Pengabdian kepada masyarakat ini mempunyai keterbatasan yaitu tidak melakukan pre-test dan post-test pada anak-anak sebagai tolak ukur pengetahuan gizi sehingga perlu dilakukan tindakan selanjutnya agar dapat dilakukan monitoring dan evaluasi kondisi gizi anak-anak di Wilayah Tenggilis Mejoyo yang bekerjasama dengan puskesmas atau institusi. Adapun kegiatan lanjutan yang dapat dilakukan adalah pemeriksaan status gizi secara periodik setiap bulan, edukasi kepada orang tua teantang bagaimana melakukan monitoring kesehatan anak secara mandiri.

\section{UCAPAN TERIMA KASIH}

Kegiatan pengabdian kepada masyarakat ini didanai oleh Lembaga Penelitian dan Pengabdian Kepada Masyarakat Universitas Nahdlatul Ulama Surabaya.

\section{DAFTAR PUSTAKA}

Balitbangkes. (2018). Hasil Utama Riskesdas 2018. Jakarta: Kementrian Kesehatan Republik Indonesia.

Forichon, K. (2020). Considering Human Capital in a Multidimensional Analysis of Fragility. Working Paper. OECD Develoment Co-Operation Working Paper 80.

Hanna, R., \& Olken, B. (2020). Hasil terkini dari survei daring tentang dampak ekonomi akibat COVID19 di Indonesia. J-PAL Asia Tenggara (J-PAL SEA).

Jawaldeh, A. A., Doggui, R., Borghi, E., Aguenaou, H., Ammari, L. E, Abul-Fadl, A., \& McColl, K. (2020). Tackling childhood stunting in the Eastern Mediterranean Region in the context of COVID-19. Children, 7(11), 239. https://doi.org/10.3390/children7110239

Kumar, A., Nayar, K. R., \& Bhat, L. D. (2020). Debate: COVID 19 and children in India. Child and Adolescent Mental Health, 25(3), 165-166. https://doi.org/10.1111/camh.12398

Laborde, D., Martin, W., Swinnen, J., \& Vos, R. (2020). COVID-19 risks to global food security. Science, 369(6503), 500-502. https://doi.org/10.1126/science.abc4765

Peraturan Menteri Kesehatan Nomor 2 Tahun 2020 tentang Standar Antropometri Anak.

Roberton, T., Carter, E. D., Chou, V. B., Stegmuller, A. R., Jackson, B. D., Tam, Y., Sawadogo-Lewis, T., $\&$ Walker, N. (2020). Early estimates of the indirect effects of the COVID-19 pandemic on maternal and child mortality in low-income and middle-income countries: A modelling study. The Lancet Global Health, 8(7), E901-E908. https://doi.org/10.1016/S2214-109X(20)30229-1

Statistik, B. P. (2012). Survei Demografi dan Kesehatan Indonesia 2012. Jakarta: Badan Pusat Statistik. 
ABDIMAS: Jurnal Pengabdian Masyarakat Universitas Merdeka Malang Volume 6, No. 2, May 2021: 271-278

UNICEF. (2014). Nutrition. Retrieved from: https://www.unicef.org/indonesia/id/nutrisi

WHO. (2020). UNICEFMHO/The World Bank Group joint child malnutrition estimates: Levels and trends in child malnutrition: key findings of the 2020 edition [Report]. Retrieved from: https:// www.who.int/publications/i/item/jme-2020-edition

Wiresti, R. D. (2020). Analisis dampak work from home pada anak usia dini di masa pandemi Covid-19. Jurnal Obsesi: Jurnal Pendidikan Anak Usia Dini, 5(1), 641-653.

https://doi.org/10.31004/obsesi.v5i1.563 